\title{
Studies on recovery of heavy metals from tannery wastewater
}

\author{
Abhimati Shukla', Zainab Mahmood², Lalit Kumar Singh ${ }^{2}$ \\ Department of Biochemical Engineering, School of Chemical Technology, Harcourt Butler Technical University, Kanpur, INDIA \\ *Corresponding Author: e-mail: abhimati.shukla1991@gmail.com, Phone: +91-7081249617
}

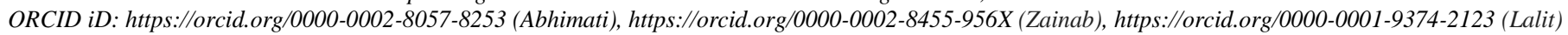

\begin{abstract}
Heavy metal salts are widely used in the tanning process in the form of Chrome alum and Chromium[III] sulfate. It is a highly toxic metal and cannot be degraded thus deposited and incorporated in water, sediment and aquatic ecosystems which poses various respiratory, skin and other health issues to humans and also cause serious issues to microbial, plant and aquatic life. The cost of these heavy metal salts is high due to which the tanners need a lot of investment for the tanning process because of its abundant use. So, to overcome such issues numerous techniques have been developed for the recovery and reuse of these heavy metal salts from the wastewater of the tanneries to reduce the pollution in the wastewater streams and exempt the tanners from the high cost of these salts.
\end{abstract}

Keywords: Chrome, chromium[III] sulfates, tanneries, adsorption, membrane separation.

Cite this article as:

Shukla A., Mahmood Z., Singh L.K. 2021. Studies on recovery of heavy metals from tannery wastewater. International Journal of Engineering, Science and Technology, Vol. 13, No. 1, pp. 76-80. doi: 10.4314/ijest.v13i1.11S

Received: December 1, 2019; Accepted: February 5, 2021; Final acceptance in revised form: March 31, 2021

This paper was earlier presented at the International Conference on Energy, Environment \& Material Sciences (ICE2M), 1-3 December 2019 and substantially improved for this Special Issue. Guest Editor: Dr. Sri Niwas Singh, Professor (HAG), Department of Electrical Engineering, Indian Institute of Technology Kanpur, 208016 (U.P.) India, former Vice-Chancellor, Madan Mohan Malviya University of Technology Gorakhpur (April 2017 to July 2020).

\section{Introduction}

Heavy metal pollution is a serious issue these days due to the amounts in which these are released from the industries. These being non-renewable resource are being wasted and dumped in the environment, causing serious health issues to both humans and animals and also to aquatic and plant life. The plants and animals living in the water require oxygen for their living, which they get by the decaying process of solid waste present in the water. The heavy metal pollution can impact the fish and wildlife populations by harming them, can lead to oxygen depletion and beach closures, and also contaminates drinking water.

There are around 2,000 tanneries in the country with an annual processing capacity of over 500,000 tonnes of hides and skins. In Uttar Pradesh there are around 400 tanneries which cause pollution by discharging effluents high in organic and inorganic dissolved and suspended solids content and contain toxic metal salt residues. [The Environment Protection Rules, Schedule VI, 1986]. The effluent from leather processing contains organic matter, heavy metals, sulphide, and solid waste. The quality of soil and groundwater has effect on the fertility of soil, so the treatment of sludge is necessary for the betterment of the society. 


\section{Heavy metals in industrial water}

Metals in wastewater when exceed the permissible limit, cause severe damage to the environment and human health like increasing levels of Cadmium causes lung damage, gastrointestinal issues, kidney damage, and death. Chromium causes skin irritations, difficulty in breathing, ulcers, anemia, and harm to the male reproductive system. Arsenic can cause skin manifestations, visceral cancers and vascular diseases. Zinc can cause depression, lethargy, neurological signs and increased thirst and Mercury leads to damage of the brain and nervous system and is very toxic to the human body. [Barakat, et. al, 2010].

The toxicity of heavy metals and their bioaccumulation poses a serious threat as metals cannot be broken down; their toxicity can only be reduced. Industries like Tanneries, Textile industries, Electroplating industries, etc. being the major cause of heavy metal pollution, release large concentrations of heavy metals in their effluents.

The tanneries are known to be very polluting due to the discharged effluents which have high concentration of organic and inorganic matter, dissolved and suspended solids, chromium and sulphides. A significant part of the chemicals used in the processes of leather processing are not actually absorbed, but are discharged in the environment. [Gupta, et. al., 2007]. The difficulty in treatment of tannery effluent is due to the complex nature of the industry and the chemicals used in the leather processing. [Islam, et. al, 2014]. The step by step process of the leather processing with chemicals used and those charged in the effluent is shown in the Fig. 1 given below. In the figure it can be seen that the heavy metal salts are used in the tanning and re-tanning process iwhich is discharged in the effluent in multiple steps i.e. tanning, sammying, chrome splitting, shavings, re-tanning, sammying and buffing, trimmings.

\section{Processes for recovery of metals}

There are various physical, chemical, physico- chemical and biological processes which are used conventionally for the recovery of heavy metals from waste water like membrane filtration, electrodialysis, chemical precipitation, biosorption, etc. The physical separation techniques include mechanical screening, hydrodynamic classification, gravity concentration, flotation, magnetic separation, electrostatic separation, and membrane separation. [Dermont, et al., 2008]. The chemical processes for removal of heavy metals mainly include chemical precipitation, adsorption, ion exchange and electrochemical deposition. The chrome recovery plants setup, under Ganga Action Plan I [Chrome recovery and reuse as a clean technology in the leather industry in Kanpur under Ganga action plan], in tanneries use chemical precipitation method for Chromium recovery in which $\mathrm{MgO}$ was used as an alkali for chrome precipitation. The various biological processes used include biosorption by using inactive, dead biomass of algae, bacteria, fungi and yeast, various agricultural by-products can also be used as adsorbents like adsorption on hazelnut shell, rice husk, coconut shell, maize cub, etc. [Babel, et. al, 2003]. There are various biopolymers which possess various different functional groups like hydroxyls and amines. The binding capacity of these biopolymers increases with higher $\mathrm{pH}$ due to polymerization reaction [Crini, 2005].

Due to their increasing concentrations and the issues arising, various methods have been developed for removing and reducing the heavy metal pollution. The various methods used are- chemical methods like coagulation, precipitation, etc. physical methodsfiltration, membrane separation, etc. electrochemical methods- electrodialysis, biological methods- biosorption, bioaccumulation, bioreduction, etc. The processes to be discussed in this review include biosorption, membrane separation and electrochemical process.

\section{Biosorption}

Various researches have been carried out on different biological materials i.e. the use of micro-organisms [fungi, algae and bacteria] and plants [living or dead] for their ability to adsorb heavy metals from the wastewater. This utilizes microorganisms in living or dead state, or with chemically modified cell wall using acid or alkali treatments, or in immobilized state, for the removal and recovery of heavy metals from the wastewater streams. Mahadavan and Daniel [2018] studied biosorption on immobilized Aspergillus awamori and found the maximum removal of chromium to $399.13 \mathrm{mg} / \mathrm{g}$ at $25^{\circ} \mathrm{C}$ and $\mathrm{pH}$ of 11.5 for an initial concentration of $500 \mathrm{mg} / \mathrm{L}$. Cr [VI] removal from from aqueous solution was studied using dead algal biomass of $C$. tamariscifolia. The maximum uptake capacity of $81.96 \mathrm{mg} / \mathrm{g}$ was reported by Bellatmania et. al. [2018] . Bano et. al. [2018] studied biosorption of cadmium, copper, ferrous, manganese, lead and zinc using halophilic fungi comprising Aspergillus flavus, Aspergillus gracilis, Aspergillus penicillioides, Aspergillus penicillioides, Aspergillus restrictus and Sterigmatomyces halophilus out of which A. falvus and S. halophilus showed good rate of adsorption for all heavy metals studied with an average of $86 \%$ and 83\% respectively [Bano, et. al, 2018]. In a study by Xu et. al. [2018] on multi-metal resistant $P$. chrysogenum XJ-1, whichwas used as biosorbent for removal of $\mathrm{Cu}^{2+}$ and $\mathrm{Cr}^{6+}$ The maximum biosorption capacity for $\mathrm{Cu}^{2+}$ was $42.83 \pm 0.57 \mathrm{mg} / \mathrm{g}$ at $\mathrm{pH} 5.0$ and that for $\mathrm{Cr} 6+$ at $\mathrm{pH} 3$ was $52.69 \pm 1.68 \mathrm{mg} / \mathrm{g}$, [Xu, et. al. 2018].

\section{Membrane filtration}

Various types of membrane filtration processes such as ultra filtration, nano filtration and reverse osmosis have been studied depending upon the size of the particle that can be retained the membranes were designed and employed for heavy metal removal 
from wastewater. In a research by Peydayesh et. al. [2019] amyloid-activated carbon hybrid membranes were used for removing four heavy metals: chromium, nickel, silver and platinum. The concentration of the metals i.e. chromium, silver, nickel and platinum was reduced to $1.26,0.3,0.3,0.03 \mathrm{ppb}$, respectively, when the initial concentration was 174, 212, 206 and $135 \mathrm{ppb}$ respectively. Ali et. al. [2018] studied plasma- treated CNT membranes for removal of zinc. The P-CNT membranes effectively removed $100 \%$ of zinc from synthetic waters and approximately $80 \%$ of zinc from a wastewater.

The separation and recovery of heavy metals was done by Tang and Qiu [2019] using shear-induced dissociation coupling with ultrafiltration [SID-UF] for selective recovery of nickel, zinc and copper from electro-plating effluent using poly [acrylic acid] sodium [PAAS] and copolymer of maleic acid and acrylic acid [PMA] as complexants respectively. The results showed that in the case of PAA-metal complexes the order of shear stabilities is PAA-Zn>PAA-Cu>PAA-Ni, and that of PMA-metal complex is PMA-Cu> PMA-Ni> PMA-Zn. Ates and Uzal [2018] studied recovery of heavy metals: nickel, chromium, aluminium from aluminium anodic oxidation wastewaters. The removal efficiencies reported for all the heavy metals: aluminium, nickel and chromium were 99, 99 and 94 respectively using NF-270 membrane. Similarly, SW 30 RO membrane was also highly successful to remove heavy metals giving $99 \%$ efficiency for aluminium, $94 \%$ for chromium and $99 \%$ for nickel.

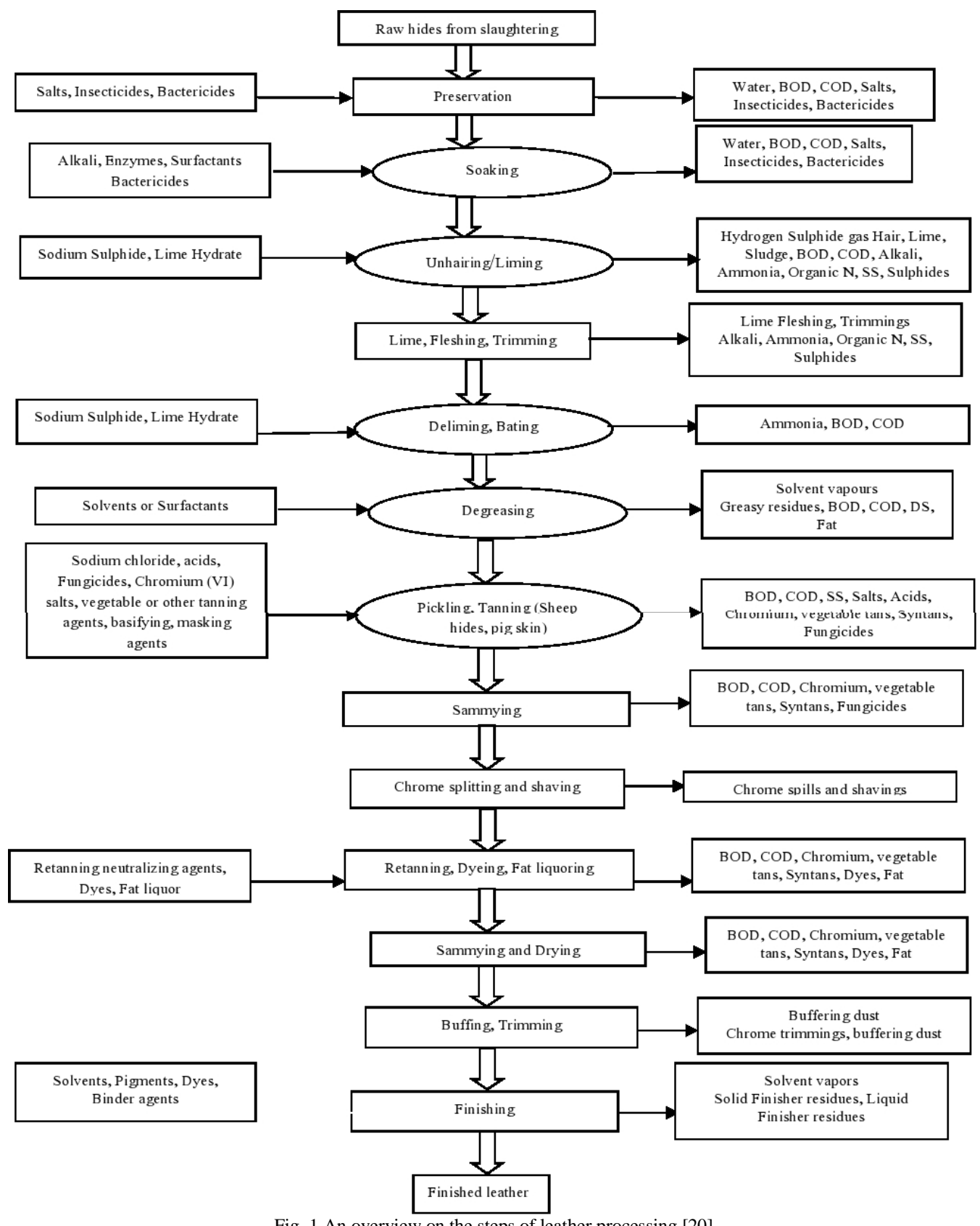

Fig. 1 An overview on the steps of leather processing [20] 
Table 1. Comparison of efficiency of removal of heavy metal using different techniques

\begin{tabular}{|c|l|l|l|}
\hline S.No. & Technique & Heavy metals removed & Reference \\
\hline 1. & Biosorption & $86 \%$ & {$[$ [Bano, et. al, 2018] } \\
\hline 2. & Membrane Filtration & $100 \%$ & [Ali, et.al, 2019] \\
\hline 3. & Electrochemical treatment & $>99 \%$ & [Jakobsen et. al, 2004] \\
\hline
\end{tabular}

\section{Electrochemical treatment}

Electrodialysis is a technique which focuses on separation and recovery of heavy metals using charged membranes. This process basically depends on the membrane size and the physical and chemical properties of the heavy metals. Ning et al.[2019] studied recovery of copper $\left[\mathrm{Cu}^{+2}\right]$ from dilute $\mathrm{Cu}^{+2}$ concentration wastewater $[500 \mathrm{mg} / \mathrm{L}]$ using jet electrodeposition. The efficiency reported was more than $97.4 \%$ with a satisfied current efficiency of $77.2 \%$, the deposited $\mathrm{Cu}$ was in bulk state and was easily separated from the cathode . In a study by Min et. al. [2018] the separation of heavy metals: copper $\left[\mathrm{Cu}^{2+}\right]$ and nickel $\left[\mathrm{Ni}^{2+}\right]$ was done from electroplating wastewater using electrodialysis. They analyzed that the voltage used is the key factor responsible for separation efficiency. The separation efficiency increased with increase in voltage, but excessive voltage lead to concentration polarization and the efficiency decreased. The removal efficiencies of $\mathrm{Cu}^{2+}$ and $\mathrm{Ni}^{2+}$ was $>99 \%$ at $12 \mathrm{~V}$. Jakobsen et al. [2004] studied removal of Cadmium from wastewater using electrodialysis. A set of three experiments were done where the sludge was suspended in distilled water where removal was $69 \%$, in citric acid where removal was $70 \%$ and in nitric acid where removal was $67 \%$.

\section{Conclusion}

In recent years various new advancements have been done in the technologies being used for the recovery and removal of heavy metals from the wastewater streams. The government has also become very rigid for the treatment of effluent waste water. In the literature survey done, we conclude that in terms of removal, membrane filtration and electrodialysis give greater efficiency but the operational cost is also very high due to membrane fouling and energy consumption. Biosorption requires low operational cost as it is performed using industrial by-products and can be operated easily with high metal binding capacities.

\section{References}

Ali S., Shah, I.A., Ahmad, A., Nawab, J. and Huang, H., 2019. "Ar/O2 plasma treatment of carbon nanotube membranes for enhanced removal of zinc from water and wastewater: a dynamic sorption-filtration process," Science of the total environment, volume 655, pp 1270-1278., 2019. https://doi.org/10.1016/j.scitotenv.2018.11.335

Ates N. and Uzal N. 2018. "Removal of heavy metals from aluminium anodic oxidation wastewaters by membrane filtration," Environment Science and Pollution Research, volume 25 , pp 22259-22272., 2018. https://doi.org/10.1007/s11356-018-2345-z

Babel S. and Kurniawan T.A. 2003. "Low- cost adsorbents for heavy metals uptake from contaminated water: a review." Journal of hazardous materials; vol 97[1], pp 219-243, 2003. https://doi.org/10.1016/S0304-3894(02)00263-7

Bano A., Hussain, J., Akbar, A., Mehmood, K., Anwar, M., Hasni, M.S., et al. 2018. "Biosorption of heavy metals by obligate halophilic fungi," Chemosphere, vol 199, pp 218-222., 2018. DOI: 10.1016/j.chemosphere.2018.02.043

Barakat M.A., 2010. New trends in removing heavy metals from industrial wastewater, Arabian Journal of Chemistry, Vol. 4, No. 4, pp. 361-377 ,2010. https://doi.org/10.1016/j.arabjc.2010.07.019

Belattmania Z., El Atouani S., Kaidi S., Bentiss F., Tahiri S., Reani A. and Sabour B. 2018. "Protonated Biomass of the Brown Seaweed Cystoseira tamariscifolia: A Potential Biosorbent for Toxic Chromium Ions Removal," Research Journal of Environmental Sciences. Vol. 12, pp. 106- 113. DOI: 10.3923/rjes.2018.106.113

Chrome recovery and reuse as a clean technology in the leather industry in Kanpur under Ganga action plan.

Crini G., 2005. "Recent developments in polysaccharide-based materials used as adsorbents in wastewater treatment,". Progress in polymer science; vol 30[1], pp 38-70,2005. https://doi.org/10.1016/j.progpolymsci.2004.11.002

Dermont, G., Bergeron, M., Mercier, G. and Richer-Laflèche, M. 2008. "Metal-contaminated soils: remediation practices and treatment technologies." Practice Periodical of Hazardous, Toxic, and Radioactive Waste Management; vol 12[3], pp 188-209, 2008. https://doi.org/10.1061/(ASCE)1090-025X(2008)12:3(188)

Gupta A.K., and Sinha S., 2007. "Assessment of single extraction methods for the prediction of bioavailability of metals to Brassica juncea L. Czern. [var. Vaibhav] grown on tannery waste contaminated soil," Journal of Hazardous Materials, Vol. 149, pp.144-150, 2007. https://doi.org/10.1016/j.jhazmat.2007.03.062

Islam B. I., Musa A.E., Ibrahim E.H., Sharafa S.A.A., Elfaki B.M., 2014. "Evaluation and characterization of tannery wastewater." Journal of Forest Products \& Industries; vol. 3[3], pp 141-150, 2014.

Jakobsen M. R., Fritt-Rasmussen, J., Nielsen, S. and Ottosen, L.M., "Electro-dialytic removal of cadmium from wastewater sludge," Journal of Hazardous materials, , volume 106 , pp 127-132., 2004. https://doi.org/10.1016/j.jhazmat.2003.10.005

Karabay S. 2008. Waste management in leather industry. M Sc. Thesis, Graduate School of Natural and Applied Sciences.

Mahadavan V. and Daniel D. K. "Modeling of biosorption of Chromium by immobilized whole cells of Aspergillus awamori NRRL 3112", Food Science and Applied Biotechnology, Pp 33-46, 2018. https://doi.org/10.30721/fsab2018.v1.i1.3 
Min K. J., Choi, S.Y., Jang, D., Lee, J. and Park, K.Y., "Separation of metals from electroplating wastewater using electro dialysis," Energy sources, , volume 41:20 , pp 2471- 2480., 2019. https://doi.org/10.1080/15567036.2019.1568629

Ning D., Yang C., and $\mathrm{Wu}$ H. 2019. Ultrafast $\mathrm{Cu}^{2+}$ recovery from wastewater by jet electrodeposition, Separation and Purification Technology, Vol. 220, pp. 217-221. DOI: 10.1016/j.seppur.2019.03.059

Peyadesh M., Bolisetty, S., Mohammadi, T. and Mezzenga, R. 2019. Assessing the binding performance of amyloid-carbons membranes towards heavy metal ions, American Chemical Society, Vol. 35, pp. 4161- 4170. https://doi.org/10.1021/acs.langmuir.8b04234

Tang S., and Qiu Y. 2019. Selective separation and recovery of heavy metals from electroplating effluent using shear- induced dissociation coupling with ultra filtration, Chemosphere, Vol. 236, Article 124330. DOI: 10.1016/j.chemosphere.2019.07.061

The Environment Protection Rules, Schedule VI- General Standards for discharge of Environmental Pollutants, 1986.

Xu X., Zhang Z., Huang Q. and Chen W. 2017. Biosorption performance of multi-metal resistant fungus Penicillium chrysogenum $\mathrm{XJ}-1$ for removal of $\mathrm{Cu} 2+$ and $\mathrm{Cr} 6+$ from aqueous solutions, Geomicrobiology Journal, Vol. 35, pp. 40-49. https://doi.org/10.1080/01490451.2017.1310331

\section{Biographical notes}

Abhimati Shukla, Zainab Mahmood and Lalit Kumar Singh are all of the Department of Biochemical Engineering, School of Chemical Technology, Harcourt Butler Technical University, Kanpur, India 